\title{
THE IMPACT OF TAPIOCA IMPORT ON CASSAVA PRICES IN THE DEVELOPMENT OF TAPIOCA INDUSTRY IN INDONESIA
}

\author{
Luriana Taslim*1, and Amzul Rifin*) \\ ${ }^{*}$ Department of Agribusiness, Faculty of Economics and Management, IPB University \\ Jl. Agatis, Campus of IPB Dramaga, Bogor 16680, Indonesia
}

\begin{abstract}
Indonesian governments needed to import tapioca because Indonesia's tapioca production was unable to meet the high domestic demand. The presence of imported tapioca made it hard for the local tapioca industry to compete. In the development of the tapioca industry, cassava price holds an important role as it is the main component in tapioca production. It is also an important element in determining cassava farmers' income. This study aimed to analyze the impact of tapioca import policy on Indonesia's cassava price determination and to formulate a proposal of tapioca industry development involving cassava prices. The Error Correction Model was used in this study with monthly time series data collected from January 2011 until December 2016. Results showed that the import of tapioca does not affect Indonesia's cassava price either in the short-term or long-term. However, the price and value of imported tapioca affected Indonesia's cassava prices. The government has to keep cassava prices low to boost tapioca industry growth. In order to keep getting a high income when the prices are low, cassava farmers need to increase their cassava production and productivity, which can be achieved through extensification and intensification programs.
\end{abstract}

Keywords: tapioca industry, tapioca import, price determination, cassava, ECM

Abstrak: Produksi tapioka di Indonesia tidak mampu mencukupi permintaan domestik yang tinggi, sehingga pemerintah melakukan impor. Kehadiran tapioka impor membuat industri tapioka dalam negeri lebih sulit untuk bersaing. Dalam pengembangan industri tapioka, harga ubi kayu memegang peran penting karena merupakan bahan baku utama produksi. Harga ubi kayu selain penting bagi industri tapioka juga penting bagi kesejahteraan petani. Penelitian ini bertujuan untuk menganalisis dampak impor tapioka terhadap harga ubi kayu di Indonesia dan merumuskan saran pengembangan industri tapioka melalui harga ubi kayu. Metode yang digunakan adalah Error Correction Model dengan data deret waktu bulan Januari 2011 hingga Desember 2016. Dari hasil penelitian diperoleh bahwa impor tapioka dari segi kuantitas tidak memengaruhi harga ubi kayu, baik itu pada jangka pendek maupun jangka panjang. Akan tetapi, harga dan nilai dari tapioka impor memengaruhi harga ubi kayu Indonesia secara signifikan. Pemerintah harus menjaga harga ubi kayu tetap terjangkau agar industri tapioka dapat berkembang. Agar pendapatan petani ubi kayu tetap tinggi meskipun harga rendah, petani harus meningkatkan produksi dan produktivitas ubi kayunya. Hal tersebut dapat diperoleh dengan program ekstensifikasi dan intensifikasi pertanian.

Kata kunci: industri tapioka, impor tapioka, pembentukan harga, ubi kayu, ECM

\footnotetext{
${ }^{1}$ Corresponding author:
}

Email: luriana.taslim@gmail.com 


\section{INTRODUCTION}

Tapioca demand by the user industry in Indonesia continues to increase every year. This can be seen from the increasing number of cassava, which is processed into tapioca (Table 1). Tapioca is used by various industries such as the food industry, textiles, paper, plywood, animal feed, sweeteners, drugs, and alcohol. The need for tapioca is so high that Indonesia must import tapioca as an additional supply in the country. For this domestic demand to be fulfilled, insufficient domestic production must be assisted by imports.

The number of tapioca imported by the government continues to increase almost every year, and this trend can be seen in Figure 1. This increase is relatively higher than the increase in tapioca production by the local industry (Pusdatin, 2017). Moreover, cassava production as the main raw material for the tapioca industry has also decreased (BPS, 2017). The reduced availability of raw materials is one of the causes of the inhibition of the domestic tapioca industry to develop.

The presence of imported tapioca as a competitor is also an obstacle for the local tapioca industry to develop. Products produced by the domestic tapioca industry must face more competitors with imported tapioca imports from foreign countries. Most tapioca imported by Indonesia is tapioca produced by Thailand and Vietnam. Tapioca from Thailand and Vietnam entered the domestic market at low prices, making it difficult for tapioca and cassava domestically produced to compete.

The government's reason to import tapioca is not limited to fulfilling domestic tapioca demand, but also to stabilize domestic tapioca prices. Research by Hadiwiyono et al. (2013) states that imports by the government are generally expected and have an impact on the declining prices of these products in the domestic market. Even so, the government must prevent the dependence on imported products from occurring, because they can pose a serious threat to the country's food security (Supadi, 2009).

Tapioca itself is the most imported form of cassava. As much as 99 percent of cassava imported by Indonesia is imported in tapioca form. Apart from reasons of ease of storage, cassava traded in tapioca form can extend the shelf life of cassava. Another reason is the cost of processing cassava into tapioca is high if it must be done alone by domestic entrepreneurs. Tapioca imports with affordable prices and stable availability make them more attractive to domestic industries that need tapioca flour.

The decreasing stock of cassava as raw material and the presence of imported tapioca as a competitor are both obstacles and challenges for the tapioca industry to develop. To overcome these two obstacles, the price of cassava is an important component that must be considered by tapioca entrepreneurs and also the government. The price of cassava can be an attractive factor for farmers to increase the production of cassava. In addition, the price of cassava as the main raw material for making tapioca takes a significant portion in determining the selling price of business products.

Unfortunately, cassava prices are expected to move in different directions to overcome these two obstacles. To increase the supply of cassava for the tapioca industry, market prices are expected to be high, thus providing higher incentives for farmers to plant cassava. On the other hand, to make tapioca selling prices more competitive, cassava prices are expected to be low so that raw material costs are also low. For this reason, the price of cassava must be in the appropriate position, where the price is not too low for farmers and not too high for the industry. The price of cassava must be stable at the right point so that the tapioca industry and cassava farmers can develop together.

Table 1. Proportion of cassava use for cassava and tapioca 2011-2016

\begin{tabular}{lcccccc}
\hline Production $\begin{array}{l}\text { Year } \\
\text { Result }\end{array}$ & \multicolumn{6}{c}{ Proportion of Cassava Used (\%) } \\
\cline { 2 - 7 } & 2011 & 2012 & 2013 & 2014 & 2015 & $2016^{*}$ \\
\cline { 2 - 7 } & 1.3 & 10.1 & 11.2 & 1.5 & 1.4 & 17.4 \\
\hline Gaplek & 26.8 & 23.1 & 39.9 & 29.1 & 45.9 & 49.4 \\
\hline Tapioca & &
\end{tabular}

Source: NBM, BKP in Kementan (2017), BPS (2017) (processed) *temporary value

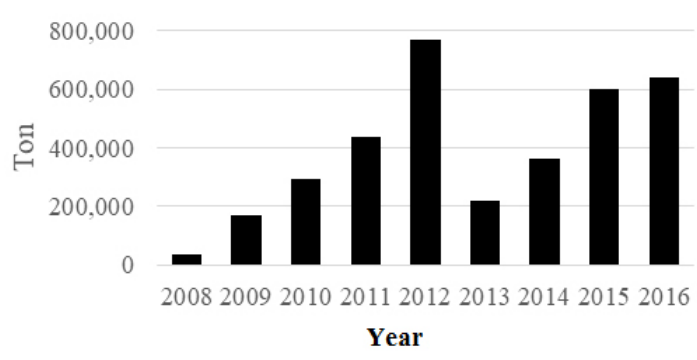

Figure 1. Indonesian tapioca import volume 2008-2016 (BPS, 2017) 
Price stability is a measure of economic success and indicates the creation of an ideal market condition. The appropriate and stable price of cassava can help the development of the tapioca industry in Indonesia. Many factors can affect the price of cassava in the country, one of which is the import of tapioca by the government. Factors that can affect the price of cassava need to be identified and measured the influence, so that the government can help control the price of cassava to develop the tapioca industry in the country.

This study analyzes the impact of imported processed products on the price of raw materials in the country that has not been done by previous studies. The related research is by Good (2012) and Zhu (2015), which examines the effect of the price of processed products on the price of raw materials. From the two studies, it was found that the price of a processed product would positively affect the price of raw materials. Based on the description the objectives of this study are: (1) to identify the factors that influence the price of cassava in Indonesia and (2) to analyze the impact of tapioca imports on the price of cassava in Indonesia.

\section{METHODS}

The study was conducted by collecting data from ministries and agencies related to the research subject. The data collection and processing were conducted from March to May 2018. This study uses secondary data in the form of monthly time series with periods from January 2011 to December 2016. The data in this study consisted of the price of domestic cassava, the volume of tapioca imports, the price of imported tapioca, the value of tapioca imports, the exchange rate of the rupiah against the US dollar, and the production of domestic cassava. Data on price and production of cassava were based on cassava data in Lampung Province as the proxy of national cassava price and production, because Lampung Province is the center of cassava production in Indonesia.

The data was obtained from the Ministry of Agriculture, the Central Statistics Agency (BPS), Bank Indonesia, the Center for Agricultural Data and Information (Pusdatin), and other relevant agencies related to this study, as well as previous related studies. Literature study references were obtained through journals, articles, LSI IPB library, FEM IPB library, and the internet that are relevant to this research.
The analytical method used in this study is the Error Correction Model (ECM). This method is used to determine the impact of tapioca imports on cassava prices in Indonesia and other factors that affect cassava prices in Indonesia. Data processing is done through Microsoft Excel and EViews 9. The software was chosen based on the reason that the software is easy to use and can be used to develop the model for this research.

This study uses a natural logarithmic equation model (Ln) with the consideration of the advantage of unit uniformity. Thus, the slope coefficient $\alpha 1$ indicates the elasticity of the dependent variable on the independent variable, namely the percentage change in cassava prices due to the percentage change in the independent variables.

The long-term equation model in this study is formulated as follows:

$$
\begin{aligned}
\text { LNHUK }_{\mathrm{t}}= & \alpha_{0}+\alpha_{1} \text { LNIMTAP }_{\mathrm{t}-1}+\alpha_{2} \text { LNHIMTAP }_{\mathrm{t}}+ \\
& \alpha_{3} \text { LNVALIM }_{\mathrm{t}}+\alpha_{4} \text { LNKURS }_{\mathrm{t}}+ \\
& \alpha_{5} \text { LNHUK }_{\mathrm{t}-1}+\alpha_{6} \text { LNPROD }_{\mathrm{t}}+\varepsilon \mathrm{t}
\end{aligned}
$$

The short-term equation model:

$$
\begin{aligned}
\Delta \text { LNHUK }_{\mathrm{t}}= & \beta_{0}+\beta_{1} \Delta \text { LNIMTAP }_{\mathrm{t}-1}+\beta_{2} \Delta \text { LNHIMTAP }_{\mathrm{t}}+ \\
& \beta_{3} \Delta \text { LNVALIM }_{\mathrm{t}}+\beta_{4} \Delta \text { LNKURS }_{\mathrm{t}}+ \\
& \beta_{5} \mathrm{LN} \Delta \mathrm{HUK}_{\mathrm{t}-1}+\beta_{6} \mathrm{LN} \Delta \text { PROD }_{\mathrm{t}}+\gamma \mathrm{u}_{\mathrm{t}-1}+\varepsilon_{\mathrm{t}}
\end{aligned}
$$

Description: $\Delta$ (first difference); LNHUK (domestic cassava price $\left(\mathrm{Rp} / \mathrm{kg}\right.$ )); $\alpha_{0}$ (long-term equation constant); $\alpha \mathrm{i}$ (regression coefficient of the independent variable to $i(i=1,2, \ldots, 6)$ long-term equation); $\beta_{0}$ (shortterm equation constant); $\beta_{i}$ (regression coefficient of the independent variable to $\mathrm{i}(\mathrm{i}=1,2, \ldots, 6)$ short-term equation); LNIMTAP $_{\mathrm{t}-1}$ (volume of tapioca import in the previous month (ton)); LNHIMTAP (price of imported tapioca $(\mathrm{Rp} / \mathrm{kg})$ ); LNVALIM (value of tapioca import (USD)); LNKURS (exchange rate of rupiah against US dollar (Rp / USD)); LNHUK $_{t-1}$ (domestic cassava price at $\mathrm{t}-1(\mathrm{Rp} / \mathrm{kg})$ ); LNPROD (domestic cassava production (ton)); $\varepsilon_{\mathrm{t}}$ ( error term); $\gamma$ (coefficient of Error Correction Term); $u_{t-1}$ (Error Correction Term). 
Data modeling with Error Correction Model also requires other tests, namely the stationarity test and data cointegration. In general, time-series data have stochastic or random properties. Data is said to be stationary if the average value is constant for each observation period, with constant variance or variance, and constant covariance. Conversely, the data is said to be not stationary if the three assumptions are not met. If non-stationary data is regressed, it will cause spurious regression, even though the number of observations is very large. Faulty regression occurs if the coefficient of determination is high enough, but the relationship between the independent variable and the dependent variable is insignificant or meaningless.

The stationarity test in this study was conducted using the Augmented Dickey-Fuller Test (ADF-test). The procedure to determine whether the data is stationary or not is by comparing the ADF t-statistic value with its critical value. The critical value of the 5 percent significance level used in this study is -2.903 . So, if the ADF t-statistics value is greater than -2.903 , it can be concluded that the data observed is stationary. Conversely, if the absolute value of the ADF statistic is smaller than the critical value, then it can be concluded that the data is not stationary.

The second test, called the Cointegration test, determines whether the variables have a long-term balance. The cointegration test looks at the stationarity of the residual in the model equation. If the residual ADF t-value is greater than the critical value, then it is concluded that the variables in the model equation have a long-term equilibrium.

The time-series data modeling must first pass the prerequisite analysis test. This test is needed so that the resulting regression model befits the diagnostic models and the statistical criteria test. Model diagnostic tests are performed to check whether the model is free from heteroscedasticity, autocorrelation, multicollinearity, and normality problems. Statistical criteria test is performed to see whether the model produced is a good enough model to be used. The model that has passed the two tests means that the validity of the model can be trusted.

This study uses the White Test to check whether the model is free from heteroscedasticity. The model is said to be free from heteroscedasticity problems if the ChiSquare probability value is greater than the 5 percent real level, indicating that the variance of all observations in the model residuals is the same. The Breusch-Godfrey test was used to check the autocorrelation in the model. If the Chi-Square probability value in the BreuschGodfrey Test is greater than the 5 percent real level, it means that the sample value used in this study is not influenced by previous sample values and is free from autocorrelation problems.

The model is said to be free from multicollinearity if each variable has a value Centered VIF that is smaller than 10 . This shows that there are no variables with values that are connected to each other. The final test carried out to ensure that the model meets the classical assumptions is the normality test with the Jarque-Bera Test. The tested value is the residual value of the model. If the probability value is greater than the real level of 5 percent, it means that the data used are normally distributed.

\section{Operational Definition}

The operational and unit definitions of the variables used in this study are as follows: 1) Imported tapioca is tapioca legally imported from abroad with the HS (Harmonized System) code 110814000; 2) The price of cassava is the selling price of cassava from the farmers in the rural area $(\mathrm{Rp} / \mathrm{kg})$, taken from the price of rural cassava producers in Lampung Province; 3) Tapioca import volume is the total amount of tapioca imported from foreign countries (tons); 4) Tapioca import value is the total cost (USD) incurred by the government to import tapioca; 5) The price of imported tapioca is the value of imported tapioca divided by the volume of imported tapioca multiplied by the exchange rate in the same month ( $\mathrm{Rp} / \mathrm{kg})$; 6) Rupiah exchange rate is the average monthly exchange rate of the rupiah against the US dollar (Rp / USD);7) Domestic cassava production is the total domestic cassava yield (tons) taken from Lampung Province production, calculated from the yield of the harvested area per month with productivity assumed to be constant for every four months.

\section{RESULTS}

\section{Data Analysis Test Results}

The data used in this study had gone through a series of tests first to obtain the best equation model. From the results of the stationarity test with the Augmented 
Dickey-Fuller Test (ADF test), it was found that all stationary variables were at the level of first difference. Another test is the cointegration test which aims to see whether the variables have long-term balance. From the stationary residuals at the corresponding level, it can be concluded that the variables have cointegration or have formed a long-term equilibrium. The ADF test results are shown in Table 2.

The next test is the model diagnostic test to see whether the model is free from problems related to the classic assumption BLUE (BestLinear Unlock Estimator). With a critical level of 5 percent, the test results show that the model is free from heteroscedasticity, autocorrelation, multicollinearity, and normality problems. Test results can be seen in the Appendix. With the fulfillment of the four classical assumptions, it can be concluded that this research model is valid for use.

\section{Factors Affecting the Price of Cassava in Indonesia}

Factors Affecting the Price of Cassava in the Long Term

The estimation results of the long-term equation model with producer-level cassava prices as the dependent variable can be seen in Table 3. The equation model obtained is deemed feasible to describe the price of cassava in the long run because the obtained Adjusted $\mathrm{R}$-squared value is 98.52 percent, which means the diversity of the cassava price can be explained as much as 98.52 percent by the independent variable used, and variables outside the model explain the rest. Of all the independent variables used, the variable price of imported tapioca, the tapioca import value, the rupiah exchange rate against the USD, and cassava price in the previous period proved to have a significant effect on the price of cassava at the producer level at the critical level of 5 percent. Meanwhile, the volume of tapioca imports in the previous period and the amount of cassava production have not been proven to influence the price of cassava in the long run significantly.

The variable of tapioca import volume has a negative relationship with the domestic cassava price, where the increase in tapioca import volume will reduce the domestic cassava price, ceteris paribus. Meanwhile, the imported tapioca price variable has a positive and significant relationship with the price of cassava. The coefficient value of 0.07 indicates an increase in the price of cassava is equal to 0.07 percent if there is an increase in the price of tapioca imports by 1 percent, ceteris paribus.

Production variables in the long-term estimation results yield a coefficient with a negative sign. This shows that the amount of cassava production each month does not affect the price of cassava. In the long run, the price of cassava is more influenced by factors other than the amount, so the amount of production does not become a major driving factor in the process of price formation.

Variable of cassava prices in the previous period were found to have a positive relationship and significantly affected current cassava prices. The coefficient value in the estimation result is 0.81 , showing that for every $1 \%$ increase in the price of the previous cassava, the current price of cassava will increase by $0.81 \%$.

Table 2. ADF Test Results of the cassava price model in Indonesia : Level and First Difference

\begin{tabular}{lcccc}
\hline Variables & \multicolumn{2}{c}{ Level } & \multicolumn{2}{c}{ First Difference } \\
\cline { 2 - 5 } & ADF t-statistic & P-value & ADF t-statistic & P-value \\
\hline Cassava price (LNHUK) & -1.550179 & 0.5025 & -5.457869 & 0.0000 \\
Tapioca import volume in the previous period (LNIMTAP_1) & -3.220696 & 0.0228 & -9.197232 & 0.0000 \\
Tapioca import price (LNHIMTAPR) & -1.509086 & 0.5233 & -5.654549 & 0.0000 \\
Cassava production (LNPROD) & -3.645444 & 0.0071 & -10.24771 & 0.0001 \\
Cassava price in the previous period (LNHUKT_1) & -1.572994 & 0.4909 & -5.566714 & 0.0000 \\
Tapioca import value (LNVALIM) & -3.371040 & 0.0153 & -6.199973 & 0.0000 \\
Exchange rate (LNKURS) & -0.499685 & 0.8844 & -9.358991 & 0.0000 \\
Residual (RES) & -5.824118 & 0.0000 & -11.42207 & 0.0001 \\
\hline Critical leve
\end{tabular}

Critical level of significance 5 percent $=-2.903566$ 
The value of tapioca imports on the estimation results has a positive relationship and a significant influence on the price of cassava. The coefficient value of 0.01 means that every time an increase in the value of tapioca imports by 1 percent, the price of cassava in the country will also increase by 0.01 percent, ceteris paribus.

Other variables that have a significant influence on the price of cassava is the rupiah exchange rate against the US dollar. The exchange rate plays an important role because cassava has a close relationship with tapioca, which is widely imported and bought in US dollars. In this study, the exchange rate has a significant impact on the price of cassava. With a coefficient value of 0.09 , the exchange rate of the rupiah against the US dollar has a positive relationship with the change in cassava prices by 0.09 percent if there is a change in the exchange rate of 1 percent in the same direction, ceteris paribus.

Factors Affecting the Price of Cassava in the Short Term

In addition to the long-run equation model, we also created a short-term model estimation for the variables forming the price of cassava. Estimations are constructed at the first difference level using the same variables as the long-term variables as well as the Error Correction Term (ECT). In the short-term equation, the production variable, the price of cassava in the previous period, and the import value have a significant effect on the domestic price of cassava. Meanwhile, tapioca import volume, imported tapioca prices, and exchange rates do not have a real effect. In the short-term equation, the data used were the result of the differencing method. Therefore, the influence of the independent variables on the dependent variable cannot be explained in terms of the coefficient; rather, only the nature of the relationship can be explained: positive or negative. The estimation results of the cassava price model in Indonesia in the short run can be seen in Table 4.

Similar to in the long-run equation, tapioca import volume does not have a significant effect on cassava prices. This influence is not significant, both in the short and long term. Tapioca import volume, whether increasing or decreasing, will not significantly affect the price of cassava in the country. However, when the increase in the volume of tapioca imports lowers the price of cassava in the long run, in the short term it increases the price of cassava. The relationship between tapioca imports and cassava prices in the short term was obtained positively or in the same direction. Nevertheless, this relationship still has no significant effect on the price of cassava.

A low R-squared value of 0.33 shows that the ability of the variables in the model to describe the price of cassava in Indonesia in the short term is only 33 percent. The variables in the model can better describe the price of cassava in Indonesia in the long run, because the $\mathrm{R}$-Squared value of the long-term equation is much higher at 0.98 . This figure shows that the variables of this study can explain 98 percent of the diversity of cassava prices in Indonesia.

Table 3. Results of estimation models of cassava prices in Indonesia in the long run

\begin{tabular}{ll}
\hline Variables & Coefficients \\
\hline $\begin{array}{l}\text { Tapioca import volume in the previous } \\
\text { period }\end{array}$ & -0.000410 \\
Tapioca import price & $0.073416^{* *}$ \\
Cassava production & -0.012055 \\
Cassava price in the previous period & $0.814736^{* * *}$ \\
Tapioca import value & $0.007992^{* *}$ \\
Exchange rate & $0.095680^{* *}$ \\
C & -0.206811 \\
R-squared & 0.986529 \\
Adjusted R-squared & 0.985266 \\
\hline$* *=$ significant at 5 percent critical level & \\
$* * *=$ significant at 1 percent critical level &
\end{tabular}

Table 4. Results of estimation models of cassava prices in Indonesia in the short term

\begin{tabular}{ll}
\hline Variables & Coefficient \\
\hline $\begin{array}{l}\text { Tapioca import volume in the previous } \\
\text { period }\end{array}$ & 0.001204 \\
Tapioca import price & 0.095118 \\
Cassava production & $-0.019031 * *$ \\
Cassava price in the previous period & $1.059085^{* * *}$ \\
Tapioca import value & $0.008293^{* * *}$ \\
Exchange rate & 0.049968 \\
ECT & $-0.933698 * *$ \\
C & -0.000383 \\
R-squared & 0.327175 \\
Adjusted R-squared & 0.251211 \\
\hline$* *=$ significant at 5 percent critical level & \\
$* * *=$ significant at 1 percent critical level & \\
\end{tabular}


In the short-term equation, the error correction term or ECT value is formed with a coefficient value of -0.93. ECT corrects short-term balance that has not yet reached a long-term balance. ECT is also called the speed of adjustment because it shows how fast it takes to reach long-term balance. The magnitude of ECT approaching one means that the speed of the model in this study is good enough to reach its long-term balance immediately.

\section{The Impact of Tapioca Imports on Cassava Prices in Indonesia}

The cassava price equation model in Indonesia produced by this study shows that tapioca import volume does not significantly affect domestic cassava prices. The influence is not significant, both in the long term and short term. The number of imported tapioca that has continued to increase over the last few years has not been proven to have an impact on the price of cassava in Indonesia. The reason for this could be due to the proportion of tapioca imports, which amount to only 10-15 percent per year of total domestic tapioca production, as shown in the data in Table 5. With these figures, the domestic tapioca market is still controlled by local producers. Thus, a greater influence on the price of cassava is owned by domestic tapioca production.

Unlike the volume of imported tapioca, the price of imported tapioca significantly affects the price of cassava in Indonesia. The price of imported tapioca and domestic cassava prices have a positive relationship: when the price of imported tapioca rises, then the price of domestic cassava also rises. The price of imported tapioca has a greater and more significant effect than the volume effect of imported tapioca on the price of cassava. This shows that the price of cassava is more sensitive to price information from imported tapioca than the volume of imported tapioca.

Tapioca import policy is a step taken by the government to meet tapioca demand while simultaneously stabilizing domestic prices. Imports are expected to fill the existing shortage and prevent price increases which can be caused by tapioca scarcity. Nevertheless, imports are often seen as negative, because imports are reducing GDP while exports will increase GDP. This makes imports considered a bad thing for the economy.

According to Manzella (2013), imports also bring benefits to the economy. In his writings, it is said that imports provide wider options for consumers in determining quality. Imports bring in products that cannot be obtained or produced domestically so that each imported item is a new item for the people of the importing country. Imports also suppress inflation, which may arise if price fluctuations result from unfulfilled shortages. Imports offer access to products at lower prices, so consumers can buy goods with less money. With these savings, then consumers will have more income to spend. The most important thing about imports is that domestic producers will be increasingly competitive, either by increasing quality or reducing costs.

Table 5. Volume of tapioca supply and use in Indonesia 2011-2016

\begin{tabular}{lcccccc}
\hline \multicolumn{1}{c}{ Explanation } & \multicolumn{7}{c}{ Year } \\
\cline { 2 - 7 } & 2011 & 2012 & 2013 & 2014 & 2015 & $2016^{*}$ \\
\hline A. Supply (000 Ton) & 2141 & 2307 & 2831 & 2153 & 4000 & 4000 \\
\hline 1. Production & & & & & & \\
- Cassava input & 6432 & 5573 & 9547 & 6510 & 12192 & 12067 \\
- Tapioca output & 1802 & 1561 & 2674 & 1824 & 3415 & 3380 \\
2. Imports & 435 & 758 & 220 & 365 & 596 & 630 \\
3. Exports & 96 & 12 & 63 & 36 & 11 & 10 \\
\hline B. Domestic Consumption (000 Ton) & 2140 & 2307 & 2831 & 2153 & 4000 & 4000 \\
\hline 1. Animal feed & 0 & 0 & 0 & 0 & 0 & 0 \\
2. Seedlings & 0 & 0 & 0 & 0 & 0 & 0 \\
3. Processed for: & & & & & & \\
- Food & 0 & 0 & 0 & 0 & 0 & 0 \\
- Non-food & 381 & 411 & 504 & 383 & 712 & 712 \\
4. Scattered & 15 & 16 & 20 & 15 & 28 & 28 \\
5. Food item & 1744 & 1880 & 2307 & 1755 & 3260 & 3260 \\
\hline
\end{tabular}


Tapioca import provides the benefits as mentioned above. The existence of imported tapioca extends the choice for consumers to choose the right tapioca as raw material. The presence of imported tapioca was also immediately responded to by domestic tapioca producers. Local producers see imported tapioca as a highly competitive product with a low price and availability that tends to be stable. Unfortunately, not all local tapioca producers respond to imported tapioca by increasing competitiveness. Many tapioca factories reduce their production capacity or even stop their entire operations. The price of imported tapioca is so low that it makes it difficult for local producers to have to suppress the price of raw materials, namely cassava, further. Meanwhile, farmers are not willing to sell their cassava at such a low price. The creation of a more competitive market due to the presence of tapioca imports has not been realized at this time.

\section{Managerial Implications}

The problem experienced by economic actors in Indonesian cassava agribusiness is getting the appropriate cassava prices for the producers (farmers) and the industry, especially tapioca producers. The price is appropriate when all stakeholders live well. The price of cassava needs to be in such a position that it does not harm the farmers nor the industry. The price of cassava is expected to be not too low for farmers and not too high for tapioca producers.

Prices that benefit all parties can be achieved when Indonesian cassava has good competitiveness. In fact, competitiveness can be increased through the development of existing products. However, repairing or modifying products means that they involve substantial research and development expenditure (Kartika et al. 2018). The tapioca industry in Indonesia is currently still dominated by small businesses with limited capital. So the means to improve competitiveness by improving products is not appropriate for the tapioca industry right now.

One component of competitiveness that has been proven to have a significant effect in this study is the import of tapioca prices. Tapioca import prices significantly influence the price of cassava. Therefore, in order to obtain low domestic cassava prices, the government must maintain the price of imported tapioca to remain affordable. The government's policy to import tapioca so far has been considered appropriate.
Prices play an important role because they encourage economic actors' decisions in allocating resources and output (Meyer and von Cramon-Taubadel, 2004). The affordable price of cassava needs to be maintained for the success of its processing industry, tapioca industry. Tapioca industry which is currently experiencing a setback due to the closure or reduction in production capacity must be encouraged to develop. One of the factors that can encourage the development of the tapioca industry is the price of cassava as a raw material. With affordable raw material prices, average production costs will decrease and can relatively increase profits for the tapioca industry.

It is not necessary to conduct import restrictions as generally demanded by the public, as long as domestic production is still inadequate. In another meaning, tapioca import is still feasible to fulfill the demand of the tapioca user industry. The quantity of tapioca import has no influence on the price of cassava. Therefore, to control the price of cassava in the country, the government can rely on other factors such as the price of imported tapioca and the exchange rate. The low price of imported tapioca can make the price of cassava become lower, and this can benefit the tapioca industry.

Even though cassava prices are low, farmers must remain prosperous, which is indicated by high income. If farmers get a low income from selling their cassava, the availability of raw materials for tapioca producers can be threatened because farmers are going to be reluctant to continue their cassava farming business. Increasing production and productivity is the key to keeping farmers prosperous despite the low cassava prices. Increased production and productivity will make cassava farmers more competitive, without having to harm farmers' incomes. In addition to additional income, low production costs will also be obtained when farmers increase their productivity. Although in the short term a large amount of production can reduce prices significantly, high productivity will results on a relatively smaller price reduction than the additional benefits obtained by farmers.

One form of efforts to increase cassava production and productivity is to increase the area of cassava. One of the ways to decrease the cassava harvest area is to stop, one of the ways is by extending the cassava field. Land expansion by utilizing idle land can be done to increase the productivity of cassava. In addition, existing land 
must also be maintained so that there is no decrease in the cassava harvest area. Another way to increase production and productivity is by intensification. Intensification is the use of technology, fertilizers, and superior seeds so that cassava production can increase. The volume of production and productivity from tapioca processing also needs to be improved. Tapioca productivity needs to be encouraged to eliminate the dependence of domestic industries on imported tapioca. Excessive dependence on imported products will make the country easily influenced by foreign factors. Increased production also needs to be done so that tapioca factories can operate at their optimum capacity.

\section{CONCLUSIONS AND RECOMMENDATIONS}

\section{Conclusions}

In this study, the impact of tapioca imports on the price of cassava was analyzed and suggestions for the development of the tapioca industry were formulated regarding cassava prices. Using the Error Correction Model, we obtained: 1) Tapioca imports in terms of quantity do not significantly affect the price of cassava in Indonesia, both in the long term and short term, while the price of imported tapioca and the value of imported tapioca have a real influence on the price of cassava in Indonesia; 2) The tapioca industry can be developed further with affordable raw material prices and availability of sufficient raw materials. Therefore, the key to developing tapioca industry is to maintain the price and welfare of cassava farmers.

\section{Recommendations}

Based on the research results and conclusions, our suggestions are as follows: 1) The government is still eligible to import tapioca as long as domestic production has not been able to meet domestic demand. The price of cassava must be kept low so that the tapioca industry receives a low production cost and the Indonesian tapioca industry can develop. 2) Increasing production and productivity of cassava should be encouraged by the government so that farmers continue to get high incomes despite low cassava prices. Increased production and productivity of cassava can be achieved with the extensification and intensification program. Extensification can be done by utilizing idle land and maintaining existing land, while intensification can be done by using technology, fertilizers, and superior seeds.

\section{REFERENCES}

[BPS] Badan Pusat Statistik. 2017. Produksi Tanaman Pangan Angka Tetap 2016 dan Angka Ramalan I 2017. Jakarta: BPS.

Good D. 2012. Focus on soybean oil. https:// farmdocdaily.illinois.edu [9 Jan 2018].

Hadiwiyono, Firdaus M, Anggraeni L. 2013. Identifikasi banjir impor kentang dan dampaknya terhadap harga domestik kentang di Indonesia. Jurnal Ekonomi dan Kebijakan Pembangunan 2(2):156175. https://doi.org/10.29244/jekp.2.2.156-175.

Kartika YD, Rifin A, Saptono IT. 2018. Strategi pengembangan usaha pengolahan kopi arabika (studi kasus PT Golden Malabar). Jurnal Aplikasi Bisnis dan Manajemen 4(2):212-219. https:// doi.org/10.17358/jabm.4.2.212.

[Kementan] Kementerian Pertanian. 2017. Neraca bahan makanan 2011-2016. https://aplikasi2. pertanian.go.id/. [9 Jan 2018].

Manzella J. 2013. Are imports really bad for the economy and jobs?. http://www/manzelareport. com. [5 April 2018].

Meyer J, von Cramon-Taubadel S. 2004. Asymmetric price transmission: a survey. Journal of Agricultural Economics 55(3):581-611. https:// doi.org/10.1111/j.1477-9552.2004.tb00116.x.

[PUSDATIN] Pusat Data dan Sistem Informasi Pertanian. 2017. Statistik Konsumsi Pangan. Jakarta: Pusdatin.

Saptana, Hadi PU. 2008. Perkiraan dampak kebijakan proteksi dan promosi terhadap ekonomi hortikultura Indonesia. Jurnal Agro Ekonomi 26(1):21-46.https://doi.org/10.21082/jae. v26n1.2008.21-46.

Supadi. 2009. Dampak impor berkelanjutan terhadap ketahanan pangan. Jurnal Analisis Kebijakan Pertanian 7(1):87-102.

Zhu H. 2015. Price conduction mechanism of china's wheat industry chain based on VECM. Asian Agricultural Research 7(1):18-22. 